V.M. Rubish ${ }^{1}$, V.K. Kyrylenko ${ }^{1}$, M.O. Durkot ${ }^{1}$, L.I. Makar ${ }^{1}$, M.M. Pop ${ }^{1,2}$, A.A. Tarnaj $^{1}$, M.L. Trunov ${ }^{1}$, S. Mudry ${ }^{3}$, I. Shtablavyi ${ }^{3}$

\title{
Rapid formation methods of arrays of randomly distributed Au and Ag nanoparticles, their morphologies and optical characteristics
}

\author{
${ }^{I}$ Institute for Information Recording, NAS of Ukraine, 4, Zamkovi Skhody str., 88000 Uzhgorod, Ukraine, center.uzh@gmail.com \\ ${ }^{2}$ Uzhhorod National University, Narodna Square, 3, 88000, Uzhhorod,Ukraine \\ ${ }^{3}$ Ivan Franko National University of Lviv, Kyrylo i Mephodiy 8, 79005 L'viv, Ukraine
}

\begin{abstract}
Techniques and equipment for rapid formation of disordered arrays of Au and Ag nanoparticles (NPs) with specified morphology and optical characteristics have been developed. By the method of rapid (30-60 s) radiation heating of gold and silver films (4-35 nm of thickness) to temperatures about 573-693 K, arrays of Au and $\mathrm{Ag}$ NPs with the dimensions from several tens to hundreds of nanometers has been received, and the position of the maximum of the surface plasmon resonance band ( $\left.\lambda_{\mathrm{SPR}}\right)$ which is in the range of 520-597 nm for Au and 424-509 $\mathrm{nm}$ for Ag. It is established that the average size of nanoparticles depends on the thickness of gold and silver films and on the annealing temperature. It is shown that the formed Au NPs arrays can be used to study the structure of nanosized chalcogenide films by surface-enhanced Raman spectroscopy.
\end{abstract}

Keywords: nanoparticles, disordered nanoparticle arrays, transmission spectra, surface plasmon resonance.

Received 25 October 2021; Accepted 23 December 2021.

\section{Introduction}

The disordered and ordered arrays of nanoparticles of precious metals of a certain size and shape (nanoballs, nanoprisms, nanorods, nanoslits) are widely used to enhance various physical phenomena. Surface-Enhanced Raman Light Scattering (SERS) is an effective method for biological analysis molecules, living cells and substances in ultra-low concentrations, short-range structures of nanoscale chalcogenide films and its changes during annealing and laser irradiation, enhancement of photoinduced mass transport of matter in chalcogenide films, nanostructuring of their surfaces, etc. [1-13], because such arrays can lead to an increase in the electric field by several orders of magnitude due to the excitation of surface plasmon resonance (SPR).

Island-type films of noble metals are one of the most effective plasmon-active structures. In [5, 6, 9] it was shown that disordered Au NPs arrays can be formed by thermal annealing of thin nano-sized gold films in air, and the average size of nanoparticle and optical properties of arrays depend on the nominal thickness of gold films and annealing temperature. The rate of heating of metal films deposited on glass substrates also has a significant effect on the process of forming metal NPs arrays. This is especially important in the formation of metal NPs that have a significant tendency to oxidize in air (for example, silver, which oxidizes, especially at elevated temperatures). In this regard, the task of creating techniques and appropriate equipment for the rapid formation of arrays of metal nanoparticles with controlled parameters is actually.

This paper is devoted to the development of fast methods for the formation of disordered arrays of precious metals, the study of their morphology and optical characteristics.

\section{Obtaining of gold and silver nanosized films}

The deposition of nanosized films of gold and silver 
with controlled thickness was carried out on an modified vacuum device VUP-4. The method of resistive evaporation was chosen to obtain gold and silver films. In this method, the effective evaporation area is minimized and consist $(2.5 \times 2.5) \mathrm{mm}$, and additional parts of the evaporator are shielded to minimize their thermal impact on condensation conditions. The thickness of gold and silver films in the process of their deposition was controlled by photometric method and laser beam reflection $(\lambda=630 \mathrm{~nm})$. The films were deposited on glass substrates using of tantalum and molybdenum evaporators. Prior to deposition, the substrates were dry cleaning, which was carried out in several stages: washing in ethyl alcohol, mechanical wiping, boiling in isopropyl alcohol, short-term cooling in air, washing in isopropyl alcohol vapors.

The nominal thickness of the condensed metals ranged from 4 to $35 \mathrm{~nm}$ and was estimated by ellipsometry using the HORIBA Smart SE spectral ellipsometer and Delta Psi 2 software. In some cases, the film thickness was measured using an atomic force microscope (AFM) Nanoscope III Dimension 3100. Note that the values of the film thicknesses determined by the ellipsometric method and measured using AFM are satisfactorily consistent.

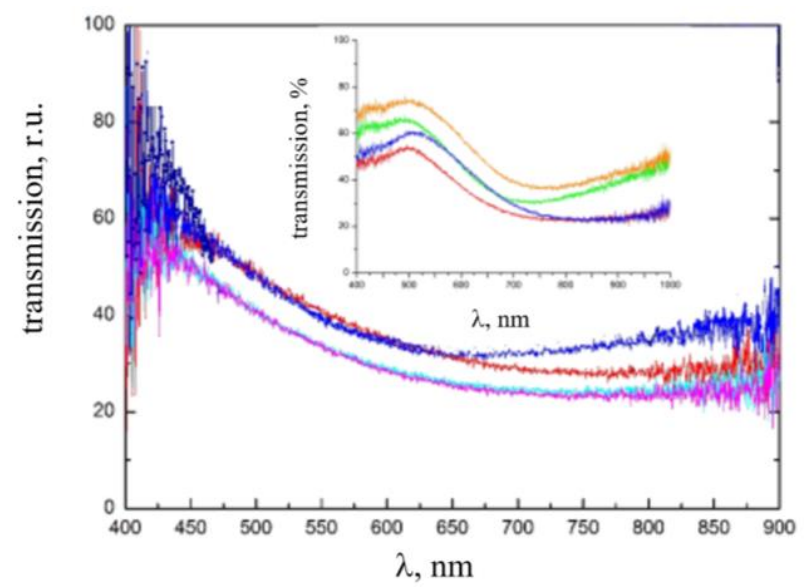

Fig. 1. Transmission spectra of silver and gold films (insert) of different thickness.

The transmission spectra of some $\mathrm{Au}$ and $\mathrm{Ag}$ films, which were measured using an Ocean Optics fiber spectrophotometer in the range of 400-1000 nm spectrum, are shown in Figs. 1. It is seen that the shape of the spectra of films of different thickness are similar.

\section{Formation of disordered arrays of nanoparticles of precious metals in air and control of their optical characteristics}

The method of radiation heating of nanosized $\mathrm{Au}$ and Ag films for the formation of NPs arrays of these metals seems to be the most attractive because it allows to implement a wide range of heating rates. In the developed device (Fig. 2) the heater is a halogen lamp (12) with a power of $250 \mathrm{~W}$ and with mirror lens condenser (1), (2), (3). This condenser concentrate the radiation of the lamp on an aluminum plate (7), the underside of which is covered with heat-resistant blackening (5). A $0.8 \mathrm{~mm}$ diameter hole is made in the center of the plate (7), through which a small part of the light flux of the lamp (12) passes through the plate and the substrate (8) with the film (9) applied to it and enters the fiber optic input (11) of the Ocean Optics spectrophotometer. This allows to continuously monitor the dynamics of changes in the transmission spectrum of the film during heat treatment. The optical neutral filter (10) is installed if necessary. The size of the aluminum plate (7) in the horizontal plane is determined by the size of the substrate, and the thickness is chosen so as to minimize the uneven temperature distribution on its surface. For the same purpose, the plate (7) is attached to the base by means of nichrome extensions with a diameter of $0.2 \mathrm{~mm}$. Measuring thermocouple (6) to obtain a reliable thermal contact, pressed directly into the plate (7). As a result, with a plate weight of $1.2 \mathrm{~g} \mathrm{(7)}$ and an average substrate weight of $1.5-2 \mathrm{~g}(8)$, the obtained maximum heating rate is $20-25 \mathrm{~K} / \mathrm{sec}$. The glass substrate does not crack, which indicates the uniformity of temperature distribution on the surface of the substrate. To reduce the heating rate in the optical path, between the output of the condenser and the gate (4), a package of quartz plates is proposed (not shown in Fig. 2 ), the number of which is selected experimentally. This approach is justified by the need to have a constant spectrum of lamp radiation (12) at different heating rates (30-300 s). It should be noted that the developed device allows for rapid radiant heating and temperature stabilization of the glass substrate with a metal film applied to it in the range of $473-773 \mathrm{~K}$.

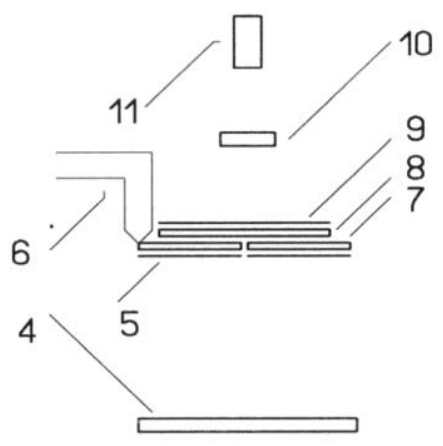

3
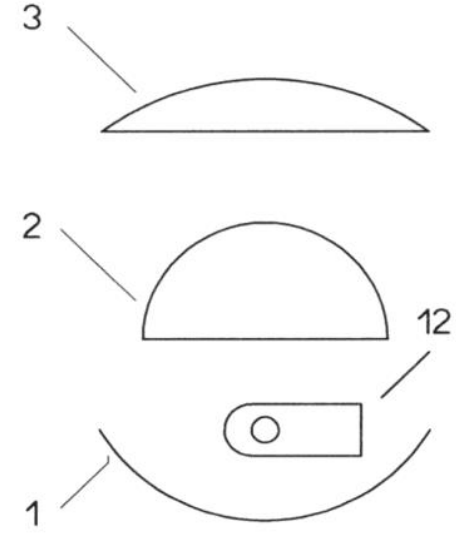

Fig. 2. Scheme of the set for obtaining disordered arrays of NPs of noble metals in air. 
Achieving of high heating rates is necessary to reduce the interaction time of the heated metal surface with air in order to prevent oxidation of the formed nanoparticles. This is actually in the formation of silver nanoparticles.

Heat treatment of metal films allows to control changes in the spectrum of SPR during the formation of NPs and to stop annealing after they reach the specified size. Investigation of the transmission spectra of arrays of $\mathrm{Au}$ and Ag NPs, which are shown in Fig. 3 and 4 were performed in the spectral region of $400-1000 \mathrm{~nm}$.

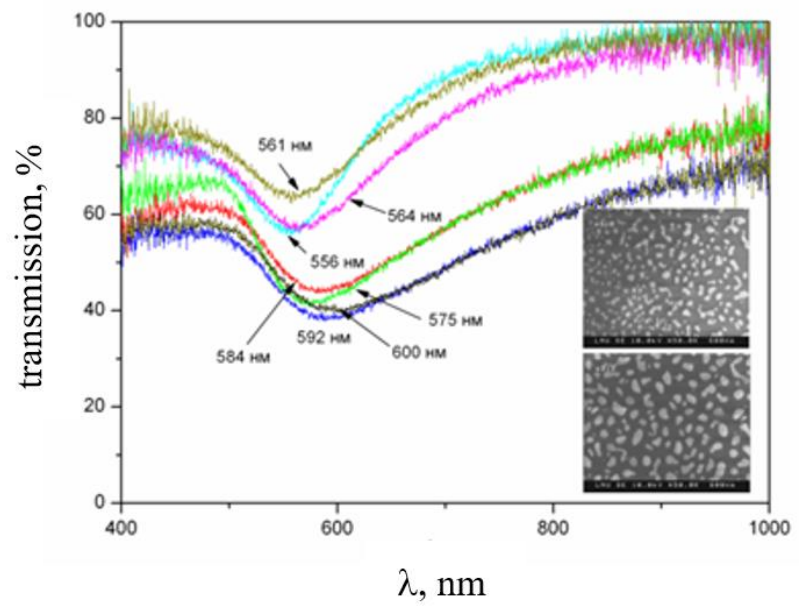

Fig. 3. Control of the position of maximum of SPR band during the formation of arrays of Au NPs in the process of radiative heating of gold films to temperatures of 653-693 K and SEM-images of arrays of different morphology (insert).

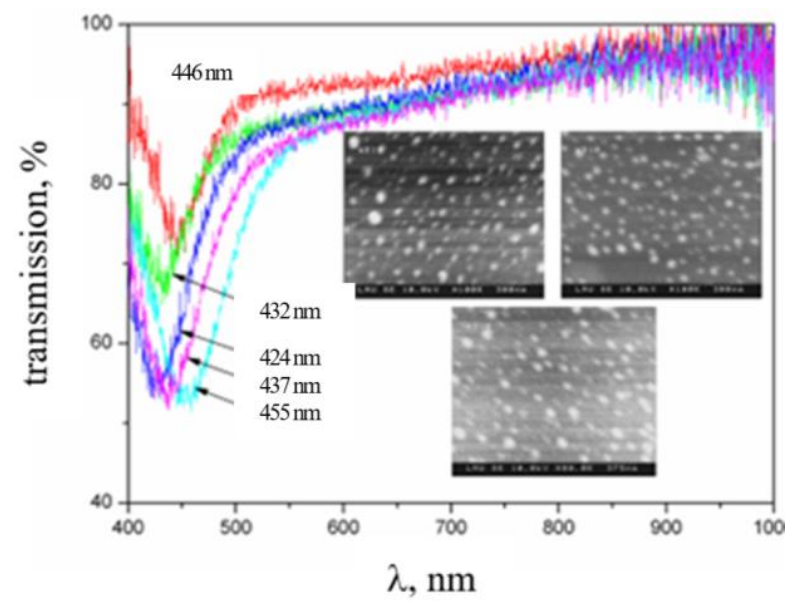

Fig. 4. Control of the position of the maximum of the SPR band during the formation of arrays of Ag NPs in the process of radiative heating of silver films to temperatures $\mathrm{T}=623 \mathrm{~K}$ and SEM-images of arrays of different morphology (insert).

The field emission of the Hitachi S-4100 scanning electron microscope in the secondary electron mode was used to analyze the morphology of the disordered gold and silver NPs arrays [14,15]. Scanning of the sample surface was performed using an electron beam at an accelerating voltage of $15-20 \mathrm{kV}$ and a current of $10 \mu \mathrm{A}$ with a spatial resolution of $10 \mathrm{~nm}$ in the mode of secondary electrons. SEM-images of some arrays of $\mathrm{Au}$ and Ag NPs, formed at different annealing modes, are shown in the inserts in Fig. 3 and 4.

Analysis of SEM images showed that the average size of NPs in arrays ranges from several tens to several hundreds of nanometers. As the nominal thickness of deposited gold and silver decreases, the surface density of nanoparticles increases and the average size of nanoparticles decreases. A similar conclusion was shown in $[5,6,16,17]$ on the basis of studies of nanoparticle arrays by AFM.

It should be noted that at relatively low temperatures and annealing times, the morphology of the surface of metal films in different areas differs significantly. For example, in Fig. 5 shows SEM images of different sections of the array $\mathrm{Ag}$, formed at $573 \mathrm{~K}$ for $30 \mathrm{~s}$ (in Figures a-c show SEM images of film sections at the edges, and in Figures d - e - closer to the center of the samples). This is probably due to the uneven temperature distribution of the $\mathrm{Ag}$ film deposited on the glass substrate from the center to its edges [15].

Thus, by rapid radiative heating of gold and silver films (4-35 $\mathrm{nm}$ of the thickness) to temperatures of 573$693 \mathrm{~K}$ in the air the arrays of $\mathrm{Au}$ and $\mathrm{Ag}$ NPs with sizes from several tens to hundreds of nanometers take place; the maximum position of the SPR band $\left(\lambda_{\mathrm{SPR}}\right)$ is in the range of 520-597 $\mathrm{nm}$ for Au NPs and 424-509 $\mathrm{nm}$ for Ag NPs. Analysis of the transmission spectra and SEM images of the Au and Ag NPs arrays suggests that with the increase in the size of the $\lambda_{\text {SPR }}$ NPs, the $\lambda_{\text {SPR }}$ shifts to the long-wavelength part of the spectrum.

\section{Formation of disordered arrays of silver nanoparticles with controlled characteristics in the process of vacuum deposition}

In order to accelerate the process of obtaining of the arrays of silver nanoparticles and prevent their contact with air, another method of their formation has been developed. In this case, the vacuum device VUP-4 (Fig. 6) was equipped with a number of units that allow the deposition of metals on heated (up to $700 \mathrm{~K}$ ) substrate and control the transmission spectra of the structures during their formation. The equipment includes: $1-$ halogen lamp $10 \mathrm{~W}(12 \mathrm{~V}) ; 2$ - protective screen; 3 resistive evaporator; 4 - glass substrate; 5 - hole with a diameter of $0.8 \mathrm{~mm} ; 6,7$ - places of installation of two halogen lamps of $100 \mathrm{~W}(12 \mathrm{~V}) ; 8$ - copper table-holder for substrates; 9 - vacuum chamber; 10 - lens; 11 neutral light filter; 12 - fiber optic input for the spectrophotometer.

The table-holder (8) is a copper plate, at the edges of which are formed cylindrical cavities (6) and (7). To the flat part of (8) the substrate (4) is attached. Two halogen lamps with a power of $100 \mathrm{~W}$ each are inserted into these cylindrical cavities. This design of the heater provides heating of the substrate to temperature of $700 \mathrm{~K}$ at a heating rate of more than $10 \mathrm{~K} / \mathrm{s}$ in vacuum. There is a hole (5) in the center of the flat part of the table. This hole due to its small diameter, does not distort the temperature distribution on the surface of the substrate. 

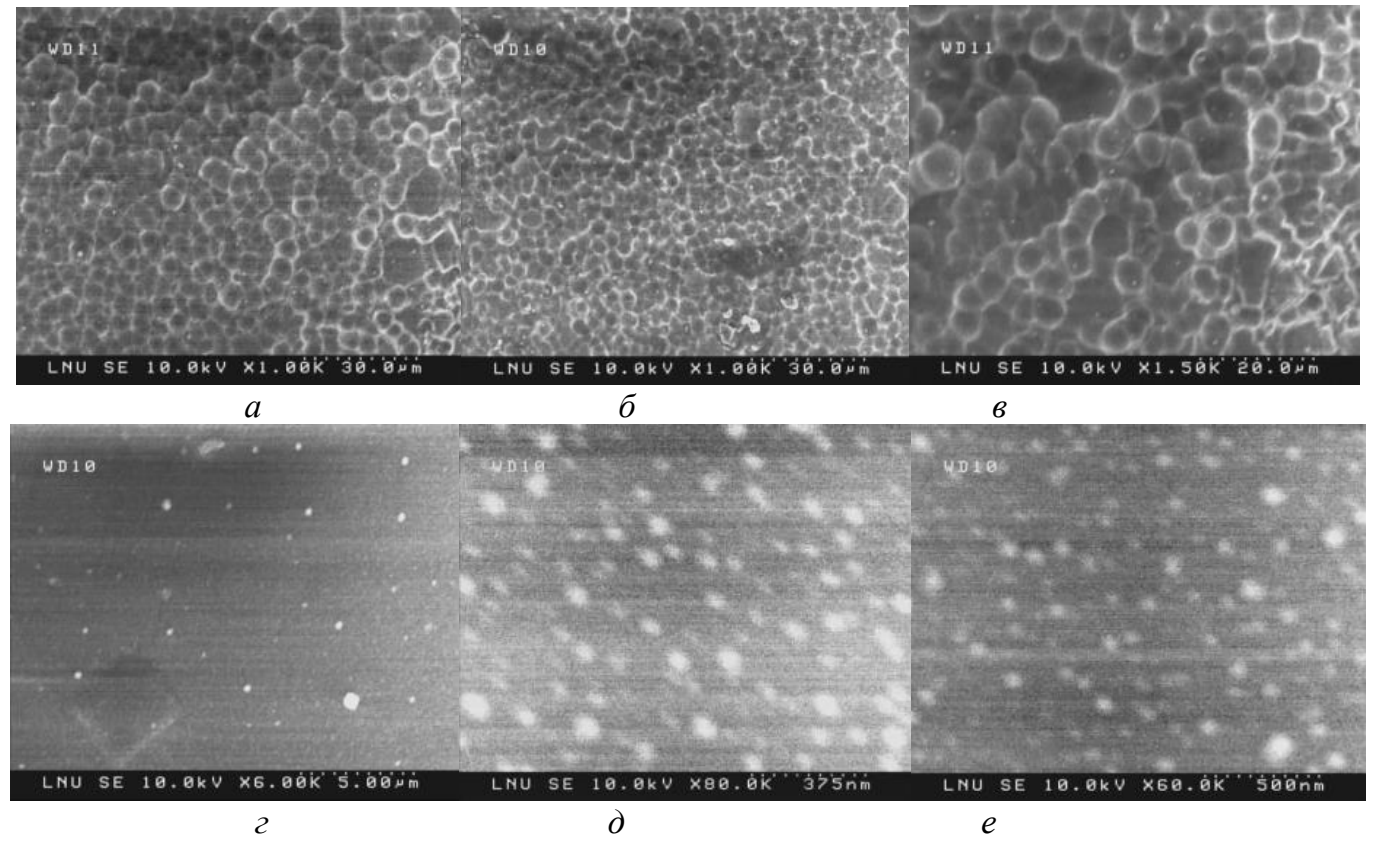

Fig. 5. SEM images of different sections of the disordered array of Ag NPs formed at temperature of $573 \mathrm{~K}$.

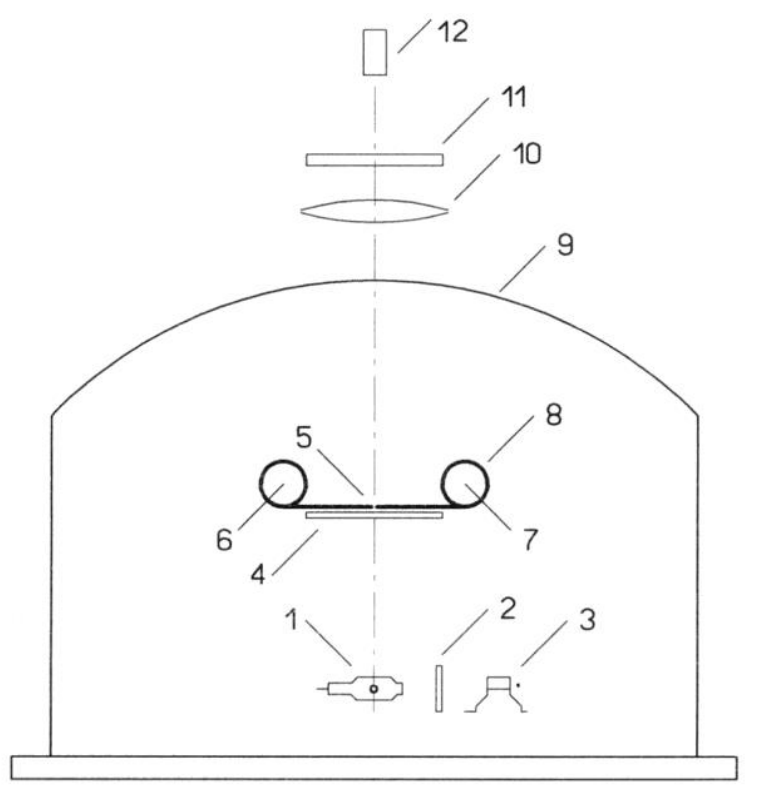

Fig. 6. The scheme of subassembly equipment for the formation of arrays of silver NPs in the process of film deposition.

Through this hole, the radiation of the halogen lamp (1), which passed through the substrate (4) with the film, goes outside the vacuum device through the transparent upper part (9). Outside the vacuum device, with the help of the lens (10), the radiation is focused on the fiber-optic input (12) of the Ocean Optics spectrophotometer. This allows continuous monitoring of the transmission spectra and, accordingly, the change in the maximum of the SPR band of NPs that are formed. Note that the transmission spectra of the Ag NPs arrays formed in vacuum are similar to the spectra shown in $[16,17]$ and Fig. 4.

Studies have shown that this method allows to form arrays of Ag NPs with a size of 20-100 nm during deposition; the positions of the maxima of the SPR bands are in the spectrum region of 480-510 $\mathrm{nm}$.

\section{Using of the disordered arrays of Au NPs as SERS-substrates for study of short range order in nanoscale chalcogenide films}

In order to clarify the possibility of practical use of disordered array of Au NPs, formed by rapid radiative heating in air of nanosized gold films as SERS substrates, the Raman spectra of freshly prepared and annealed $\mathrm{As}_{2} \mathrm{~S}_{3}$ films (with a thickness of 50 and $100 \mathrm{~nm}$ ) deposited both on uncovered substrate and the same one but covered by Au NPs were studied.

The thin films of arsenic sulfide and composite structures of "Au NPs / $\mathrm{As}_{2} \mathrm{~S}_{3}$ film" were obtained by thermal evaporation from quasi-closed effusion cells of $\mathrm{As}_{2} \mathrm{~S}_{3}$ glass on glass substrates and on the surface of arrays of gold NPs with an average size of Au 20-35 nm, $30-40 \mathrm{~nm}$ and $40-60 \mathrm{~nm}$ and $\lambda_{\text {SPR }}$ values about 532,538 and $574 \mathrm{~nm}$, respectively. Studies of the Raman spectra of freshly prepared and annealed $\mathrm{As}_{2} \mathrm{~S}_{3}$ films and composite structures of "Au NPs / $\mathrm{As}_{2} \mathrm{~S}_{3}$ film" were performed at room temperature on a Horiba Jobion-Yvon spectrometer. A laser with $\lambda=671 \mathrm{~nm}$ was used for excitation.

The studies of Raman spectra of nanosized amorphous $\mathrm{As}_{2} \mathrm{~S}_{3}$ films have shown that there is no Raman signal for both freshly prepared and annealed nominally pure films (Fig. 7, curves 1 and 2).

For these films, but deposited on arrays of gold NPs, the Raman spectra clearly show all the features of characteristic of the spectra for appropriate bulk glasses and $\mathrm{As}_{2} \mathrm{~S}_{3}$ films (micron-thick) $[11,18]$. For example, in 
Fig. 7 (curve 3) shows the Raman spectrum of annealed at $450 \mathrm{~K}$ for 1 hour $\mathrm{As}_{2} \mathrm{~S}_{3}$ film with a thickness of $50 \mathrm{~nm}$, deposited on an array of Au NPs with an average size of $30-40 \mathrm{~nm}$. For a $100 \mathrm{~nm}$ arsenic sulfide film deposited on the same array, the Raman spectrum is identical.

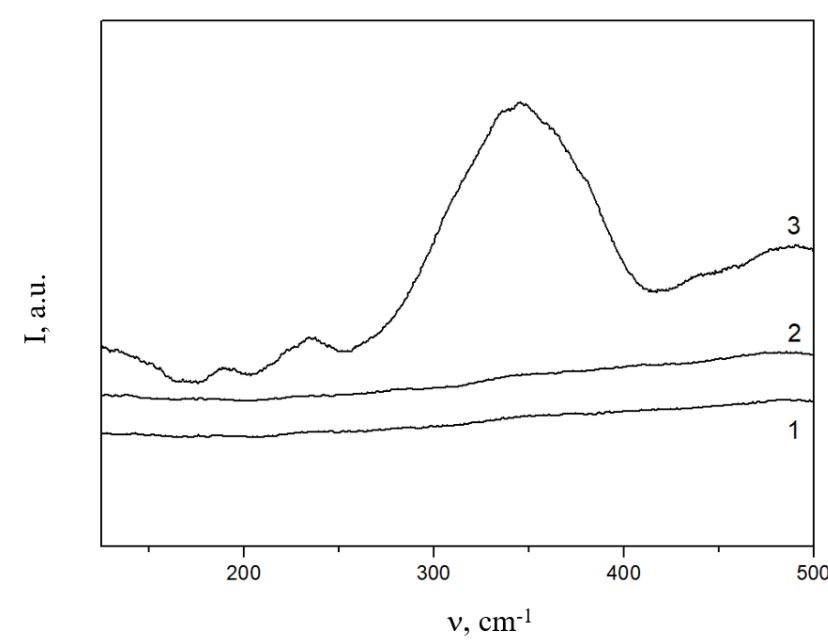

Fig. 7. Raman spectra of freshly prepared As2S3 films with a thickness of $50 \mathrm{~nm}(1), 100 \mathrm{~nm} \mathrm{(2)} \mathrm{and} \mathrm{the}$ plasmon structure $\mathrm{Au}$ NPs $/ \mathrm{As}_{2} \mathrm{~S}_{3}$ film (3), taken at $\lambda=$ $671 \mathrm{~nm}$, (see the text for details).

The Raman spectrum of the annealed nanosized $\mathrm{As}_{2} \mathrm{~S}_{3}$ film contains an intense wide band with a maximum at $343 \mathrm{~cm}^{-1}$, a number of less pronounced bands at 148, 186, 235 and $483 \mathrm{~cm}^{-1}$ and a feature (as shoulder-shaped) at $380 \mathrm{~cm}^{-1}$. It should be noted the similarity of the obtained spectrum with the spectrum of glass type of $\mathrm{As}_{2} \mathrm{~S}_{3}$ [18]. The main band in the Raman spectrum of the plasmon structure of $\mathrm{Au} \mathrm{NPs} / \mathrm{As}_{2} \mathrm{~S}_{3}$ film is due to the oscillations of As and $\mathrm{S}$ atoms in the trigonal pyramids $\mathrm{As}_{2} \mathrm{~S}_{3}$. The weak band at $148 \mathrm{~cm}^{-1}$ can be attributed to As-S-As oscillations, and the band at 483 $\mathrm{cm}^{-1}$ is attributed to S-S oscillations. Quite pronounced bands at 186 and $235 \mathrm{~cm}^{-1}$ and a peculiarity at $362 \mathrm{~cm}^{-1}$ indicate the presence in the matrix of arsenic sulfide film a number of molecular fragments with homopolar arsenic-arsenic bonds $\left(\mathrm{As}_{4} \mathrm{~S}_{4}\right)$.

It should be noted that the Raman spectra of nanosized films of arsenic sulfide deposited on arrays of Au NPs with other sizes of nanoparticles are practically indistinguishable from the spectrum shown in Figs. 7 (curve 3). Note that the effect of amplification of the Raman signal was found in the study of plasmonic structures "Au NPs / Se film" [12, 13].
The obtained results indicate that glass substrates with disordered arrays of Au NPs formed on their surface can be used as effective SERS-substrates for studies of the structure of nanosized chalcogenide films by surface amplified Raman spectroscopy.

\section{Conclusions}

The disordered arrays of $\mathrm{Au}(\mathrm{Ag})$ NPs with the size of from several tens to hundreds of nanometers can form in vacuum by the method of rapid radiation heating of thin films (4-35 nm) of gold and silver in air (at heating rates of $20-25 \mathrm{~K} / \mathrm{s}$ ) to temperatures of $573-693 \mathrm{~K}$ and by the method of deposition of silver on heated (at heating rate of $10 \mathrm{~K} / \mathrm{s}$ ) up to the same temperatures glass substrates. It was found that the position of the maximum of the SPR band of the Au NPs arrays is in the region of the spectrum 520-597 nm, and that of the Ag NPs arrays is in the range of 424-509 $\mathrm{nm}$. The average size of NPs depends on the thickness of the $\mathrm{Au}$ and $\mathrm{Ag}$ films and the temperature, and annealing time. The $\lambda_{\mathrm{SPR}}$ shifts to the long-wavelength part of the spectrum at the nanoparticle size increases.

It is shown that the formed disordered arrays of gold NPs can be used as effective SERS-substrates for the study of Raman spectra and, accordingly, for investigation of the structure of nanosized chalcogenide films.

\section{Acknowledgement}

The authors are grateful to the University of Würzburg for providing equipment for the study of materials by scanning electron microscopy.

Rubish V.M. - Professor, Dr. Sci, Head of Laboratory; Kyrylenko V.K. - Senior construction engineer; Durkot M.O. - Senior engineer-technologist; Makar L.I. - Senior Engineer;

Pop M.M. - Ph.D., assistant professor;

Tarnaj A.A. - Senior construction engineer;

Trunov M.L. - Researcher;

Mudry S. - Professor, Head of Physics of Metals Department, Dr. Sci;

Shtablavyi I. - Associate professor, Dr. Sci

[1] R.K. Chang, T.E. Furtak, (1982), Surface enhanced Raman scattering, New York: Plenum Press, pp. 379

[2] M. Moskovits, Surface-enhanced spectroscopy, Rev. Modern Phys. 57(3), 783-826 (1985); https://doi.org/10.1103/RevModPhys.57.783.

[3] I.P. Nabiev, R.G. Efremov, G.D. Chumanov, Giant Raman scattering and its application to the study of biological molecules, $\quad$ Sov. Phys. Usp. $\quad 31 \quad 31-262 \quad$ (1988); https://doi.org/10.1070/PU1988v031n03ABEH005720. 
Rapid formation methods of arrays of randomly distributed Au and Ag nanoparticles, their morphologies and optical ...

[4] D.M. Kuncicky, S.D. Christesen, O.D. Velev, Role of the micro- and nanostructure in the performance of surface-enhanced Raman scattering suhstrates assembled from gold nanoparticles, Applied Spectroscopy, 59(4), 401-409 (2005); https://doi.org/10.1366\%2F0003702053641559.

[5] M.L. Trunov, P.M. Lytvyn, P.M. Nagy, et al. Light-induced mass transport in amorphous chalcogenides/gold nanoparticles composites, Semiconductor Physics, Quantum Electronics \& Optoelectronics, 16(4), 354-361 (2013).

[6] M.L. Trunov, P.M. Lytvyn, P.M. Nagy, et al., Light-induced mass transport in amorphous chalcogenides: Toward surface plasmon-assisted nanolithography and near-field nano imaging, Phys. Status Solidi B., 251(7), 1354-1362 (2014); https://doi.org/10.1002/pssb.201350296.

[7] M.L Trunov, P.M. Lytvyn, V.A. Sterligov, et al., Formation of Nanostructures Upon Photoexcitation of Surface Plasmon Resonance in Nanocomposites Derived from Textured Gold Films and Chalcogenide Glass, Theoretical and Experimental Chemistry, 54(2), 107-113 (2018); https://doi.org/10.1007/s11237-018-9553-y.

[8] V.O. Yukhymchuk, O.M. Hreshchuk, V.M. Dzhagan, et al., Experimental studies and modeling of "starlike" plasmonic nanostructures for SERS application, Phys. Stat. Solidi B., 1800280 (1-8) (2018); https://doi.org/10.1002/pssb.201800280.

[9] A.V. Korotun, A.O. Koval', A.A. Kryuchyn, V.M. Rubish, V.V. Petrov, I.M. Titov, Nanophoton technologies. Modern state and prospects, Uzhgorod: PE Sabov A.M, 482 p. (2019).

[10] I. Csarnovics, M. Veres, P. Nemec, et al., Surface plasmon enhanced light-induced changes in Ge-Se amorphous chalcogenide-Gold nanostructures, J. Non-Cryst.Solids: X, 6, 100045 (2020); https://doi.org/10.1016/j.jnoncrysol.2020.120491.

[11] V.M. Rubish, M.O. Durkot, O.M. Hreshchuk, et al., Investigation of the short-range order structure of nanosized chalcogenide films by SERS-method, Mat. Intern. Meeting "Clusters and nanostructured materials (CNM-6)", Uzhgorod, Ukraine, pp.134-135 (2020).

[12] T.I. Yasinko, V.O. Yukhymchuk, V.M. Rubish, et al., Raman spectroscopy study of nano-sized amorphous layers of selenium and plasmon structures "Au NPs/ Se film", Mat. Intern. Meeting "Clusters and nanostructured materials (CNM-6)”, Uzhgorod, Ukraine, pp.326-327 (2020).

[13] V.M. Rubish, O.M. Greshchuk, M.O. Durkot, [et. al.], Structural studies of photosensitive composites "NPs Au/selenium film", Data recording, storage \& processing, 22(4), 12-18 (2020).

[14] M.O. Durkot, V.K. Kyrylenko, A.A. Tarnaj et al. Surface morphology and optical characteristics of arrays of randomly distributed gold nanoparticles Mat. Intern. Meeting "Clusters and nanostructured materials (CNM6)", Uzhgorod, Ukraine, pp.209-210 (2020).

[15] L.I. Makar, S. Mudry, V.M. Rubish, et al., ESEM study of surface morphology of arrays of noble metals nanoparticles, Mat. Intern. Meeting "Clusters and nanostructured materials (CNM-6)", Uzhgorod, Ukraine, pp.114-115 (2020).

[16] M.O. Durkot, V.K. Kyrylenko, P.M. Lytvyn, Formation of arrays of silver nanoparticles of different morphology and their optical characteristics, Abstr. VIII Ukrainian Scientific Conference on Physics of Semiconductors (USCPS-8), Uzhhorod, Ukraine, V.1, pp. 194-195 (2018).

[17] M.O. Durkot, V.K. Kyrylenko, P.M. Lytvyn et al., Formation of Ag nanoparticles arrays and their optical transmittance spectra, Mat. Intern. Meeting "Clusters and nanostructured materials (CNM-5)", Uzhgorod, Ukraine, pp. 163-164. (2018).

[18] V.V. Petrov, A.A. Kryuchin, V.M. Rubish, , Materials perspective optoelectronic devices, Kiev: Naukova dumka, 335 p. (2012). 
В.М. Рубіш ${ }^{1}$, В.К. Кириленко ${ }^{1}$, М.О. Дуркот ${ }^{1}$, Л.І. Макар ${ }^{1}$, М.М. Поп ${ }^{1,2}$, А.А. Тарнай ${ }^{1}$, М.Л. Трунов ${ }^{1}$, С.I. Мудрий ${ }^{3}$, I.I. Штаблавий ${ }^{3}$

\section{Швидкісні методи формування неупорядкованих масивів наночастинок Au i Ag, їх морфологія та оптичні характеристики}

${ }^{1}$ Жсгородська лабораторія матеріалів оптоелектроніки та фотоніки Інституту проблем реєстрації інформації НАН України, 88000, Ужсгород, вул. Замкові сходи, 4, Україна, center.uzh@gтаil.com

${ }^{2}$ Ужгородський національний університет, 88000, Ужгород, пл. Народна, 3, Украйна

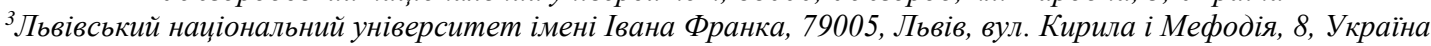

Розроблені методики та оснащення для швидкого формування у вакуумі та на повітрі неупорядкованих масивів наночастинок (HЧ) $\mathrm{Au}$ i $\mathrm{Ag}$ iз заданими морфологією та оптичними характеристиками. Методом швидкого $(30-60 \mathrm{c})$ радіаційного нагрівання плівок золота і срібла (товщиною 4-35 нм) до температур 573-693 К одержані масиви НЧ Au i Ag з розмірами наночастинок від декількох десятків до сотень нанометрів, положення максимуму смуги поверхневого плазмонного резонансу ( $\lambda$ ппР) яких знаходиться в межах 520-597 нм для НЧ Аu i 424-509 нм для НЧ Ag. Встановлено, що середній розмір наночастинок залежить від товщини плівок золота і срібла та температури відпалу. Показано, що сформовані масиви НЧ Аu можуть бути використані для дослідження структури нанорозмірних халькогенідних плівок методом поверхнево-підсиленої раманівської спектроскопії.

Ключові слова: наночастинки, неупорядковані масиви наночастинок, спектри пропускання, поверхневий плазмонний резонанс. 